\title{
URBAN AGRICULTURE AND BUDDHIST CONCEPTS FOR WELLBEING: ANURADHAPURA SACRED CITY, SRI LANKA
}

\author{
WASANA DE SILVA \\ Department of Architecture, University of Moratuwa.
}

\begin{abstract}
The first Buddhist city Anuradhapura (377 BCE-1017 CE), continues as a world heritage site. The unbroken relationship with the agriculture and irrigation landscape, apparent in the city, plays a vital role throughout the history, shapes the city and the sacred landscape. This research argues that urban agriculture in Anuradhapura establishes a 'performing system' to engage the people with the topography and the city and uplift their body and the mind for wellbeing. It illustrates that this is achieved through a process of dwelling, understanding the orientation of the place, which is a spiritual experience manifest in the landscape, cities and settlements. This research examines how and why urban agriculture engages everyday/ urban life with the topography and successfully establishes a healthy and sustainable city for wellbeing. It examines the anthropo-ethnographical and phenomenological experience, the encounters with the topography, agriculture \& irrigation and their manifestation in landscape, place, and city, achieving spiritual and sustainable place, and discusses its relevance to wellbeing and healthy city. The research methodology synthesises aspects of phenomenology, philosophy, anthropology, ethnography, landscape research, neuroscience, and Buddhist philosophy. In Anuradhapura sacred city, the everyday life of people has been devoted around large wewa (reservoirs) and vast paddy fields for the sustenance of the city as well as achieving sacred experiences. Through engaging in the laborious life of agriculture in the periphery, they experience the four noble truths and the deeper dimensions of the place, relating to the centre/orientation (physically \& non-physically) which shapes the city form affirming the Buddhist sacred city. This engagement evokes embodied agriculture landscape which brings healthy space for human wellbeing. Keywords: everyday life, embodied agriculture, orientation of the place, urban agriculture, wellbeing in Buddhist city.
\end{abstract}

\section{INTRODUCTION}

Anuradhapura (377 BCE-1017 CE) was the first Buddhist city in Sri Lanka, and the great architectural edifices in this city are invaluable sources to understand Buddhist sacred architecture and landscape. The city was nominated under the world heritage list in 1982. However, apart from the Buddhist architectural edifices, agriculture and irrigation landscape are significant, encircling the city and still functioning, since they emphasize the traditional land occupation. It is understood that agriculture and irrigation landscape play a vital role throughout the history in these sacred landscapes and settlements in Sri Lanka. How does agriculture establish a 'performing system' for landscape occupation, moreover, to continue and experience everyday life in the city/settlements and the Buddhist spiritual atmosphere? How do people working in the periphery, in agricultural fields and reservoirs, experience the centre of the city, symbols of the stupa, urban monasteries, Bodhi tree, and the spiritual context?

The research questions, why agriculture landscape is vital in Anuradhapura city, how the performing of agriculture guides the everyday life towards Buddhist concepts and universal concepts of the place. It discusses, how the 'performing agriculture landscape' evokes the Buddhist concepts and establishes a Buddhist city, to understand the orientation of the place. The research argues, that despite tiring work at the periphery of the city among the paddy fields, while having the spiritual experience of the stupa and the centre of the city and serving the clergy, people achieve both physically and non-physically, producing a healthy space for human wellbeing. 


\subsection{Methodology}

This paper examines the human engagement with the topography, agriculture \& irrigation and its manifestation in landscape, place and the city, recalling the orientation towards a spiritual and sustainable place. It discusses why this nature of humans is essential in the Buddhist sacred city and the place, and how these concepts enhance human well-being and sustainable landscape/ place/city. Although Anuradhapura sacred city has been studied from different perspectives, for example, archaeological, architectural, Buddhist, social, historical, as well as irrigation and engineering, this kind of multi-disciplinary approach to understand the co-existence of the urban and agriculture landscape is limited. De Silva [1] explained, how and why the urban agriculture and irrigation landscape are integrated in the ancient city concept Anuradhapura, and achieve a Buddhist sacred place thus a sustainable city, through a historical analysis. The present paper discusses, how urban agriculture acts as a mechanism to engage the life of the people with the topography and the city and uplift their body and mind for a healthy space and wellbeing.

The research methodology synthesises aspects of phenomenology, anthropo-ethnography, landscape research, and Buddhist philosophy to explain the active role of the body, everyday place, performing in agriculture landscape, and its manifestation in Buddhist city Anuradhapura. It employs the key concepts of dwelling [2], sense of place, process of dwelling, performance, and orientation of the place [3] in the research discussion. The four noble truths, that is, the fundamental Buddhist philosophy is examined with the contextual interpretations and explain the everyday life and the city context. Hence, both generalized and contextual concepts are employed to explain the meaning of urban agriculture in Anuradhapura.

\section{ANURADHAPURA}

A brief description of the geographical location and the history of Anuradhapura is set in context for the discussion.

\subsection{Geographical location \& urban agriculture today}

The location of Sri Lanka is at the south edge of the Indian peninsula, in the Indian ocean (Fig. 1). Lowland plains at an elevation of 0-75 $\mathrm{m}$ above the sea level surround the central

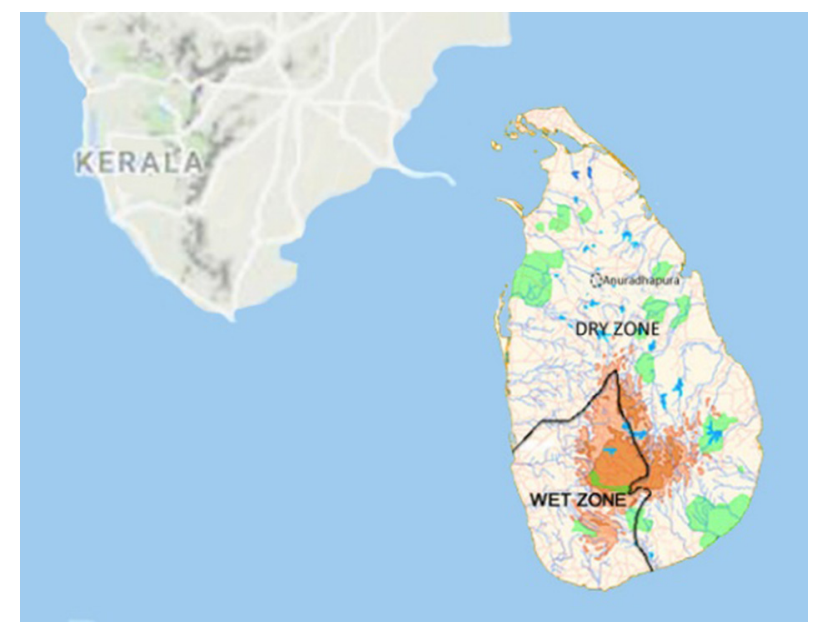

Figure 1: Location of Anuradhapura. 
mountains of Sri Lanka which rise to an elevation of 2,500 m. Many rivers and streams originating from the mountains flow in an arterial pattern across the lowland plains to the sea. Anuradhapura is located by the side of the Malwathu Oya (river) known as Kadamba nadi in early periods, in the north-central part of Sri Lanka. The city lies in an elevation of $81 \mathrm{~m}$ above the sea level, its annual average rainfall is $1450 \mathrm{~mm}$, and the temperature varies from $35^{\circ} \mathrm{C}$ to $21^{\circ} \mathrm{C}$ throughout the year. Malwathu Oya originates from the Ritigala mountain, a residual mountain in the dry zone, flows across the plains, towards the north-west, and straight north at Anuradhapura then turns north-west and flows to the sea below the Mannar (Figs. $2 \& 3$ ). Geological studies explain that during the middle stone ages, Sri Lanka was linked to the Indian sub-continent through a stretch of land from Mannar. The last separation from India happened 7,000 years ago [4], and the beginning of rice cultivation in Asian tropical countries would have been 10,000 years ago [5], as confirmed by the historical roots.

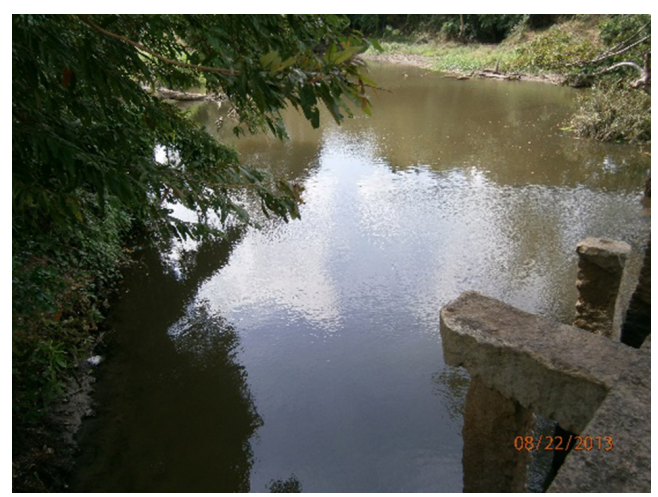

Figure 2: Malwathu Oya.

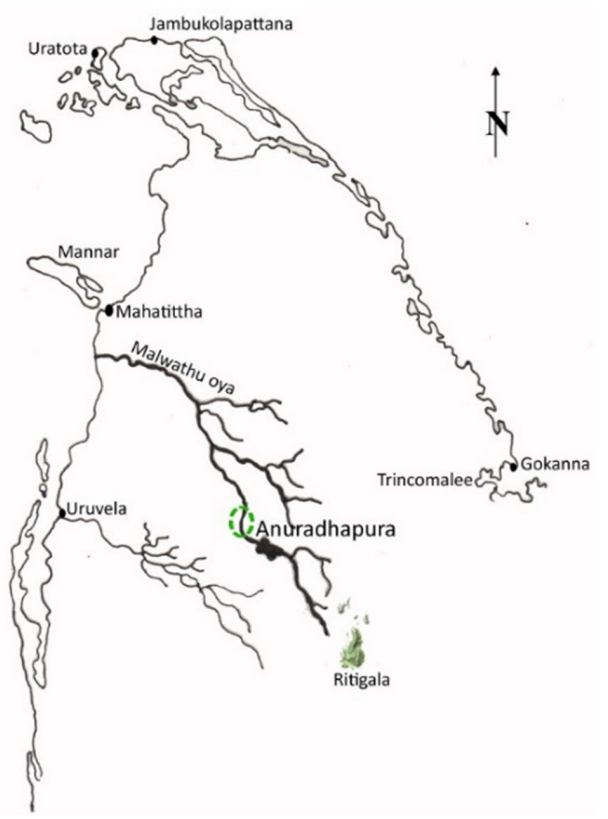

Figure 3: Malwathu Oya \& ancient ports. 
Pre-historic people from the main continent might have walked along the stretch of land and entered Sri Lanka close by Mannar, then walked along the Malwathu Oya and identified the suitability of the site Anuradhapura for a settlement. The ancient city Anuradhapura lies in a flat land area, in-between Malwathu Oya and a stretch of granite formation, comprised of rocks and boulders, caves and stone terrains (Fig. 4), which runs parallel to the Malwathu Oya, from the west side of the river. It is now confirmed that the earliest settlements originated along these rocks and cave formations [6]. In the sacred landscape rocks and caves, water, mountains, trees, and grooves are identified as sacred natural elements [7]. There are no mountains in Anuradhapura, however, the closest mountain, Mihintale, $9 \mathrm{Km}$ away, became a significant place in Buddhist history. Today, the agriculture landscape in this city is significant; six main wewa (water tanks) encircle the city, utilized for irrigation of paddy lands (Fig. 5).

Today, rice is the staple food in Sri Lanka, while there are other agriculture food products, for example, vegetables of low land grown and highland grown. The other three main agriculture products are coconut, rubber \& tea with focus on the export market. These are consequences of the colonization (1505 CE-1948 CE), which introduced dependable economy and changed the earlier land occupation system resulting in many issues today. However, still a large amount of land occupation in agriculture is based on the paddy cultivation (Fig. 6), and the majority of these are from the continuation of traditional settlement patterns, and reflect the landscape pattern of Sri Lanka. It is understood that earlier agriculture concepts were more focused on the location, topography, landscape and Buddhist concepts; that is, localization than globalization. Therefore, to understand urban agriculture landscape continuing in Anuradhapura sacred city, it is necessary to examine the historical background.

\subsection{History}

Archaeological evidences confirmed that the importance of the location of Anuradhapura, for a human settlement had been identified long ago in human history. Excavations from the citadel of Anuradhapura, 10 metres below the present ground surface, have produced substantial evidence of iron technology, breeding of horses and cattle, and paddy cultivation and wheel made clay pottery of high quality, stone tombs, and wattle and daub structures. These were identified using carbon 14 dates and confirmed that they belonged to the periods ranging from $100 \mathrm{CE}$ up to $3900 \mathrm{BCE}$ [8].

According to the written history, the origin of present Anuradhapura has connections with the migrations that happened during the 5th to 6th century BCE, from India. Accordingly, the name Anuradhapura is due to two 'Anuradha's settled at this site during different periods. The first Anuradha was a man, among the one of 700 followers of Vijaya (prince), who came from India, and landed on the north-west coast in Sri Lanka during the 5th to 6th century [9].

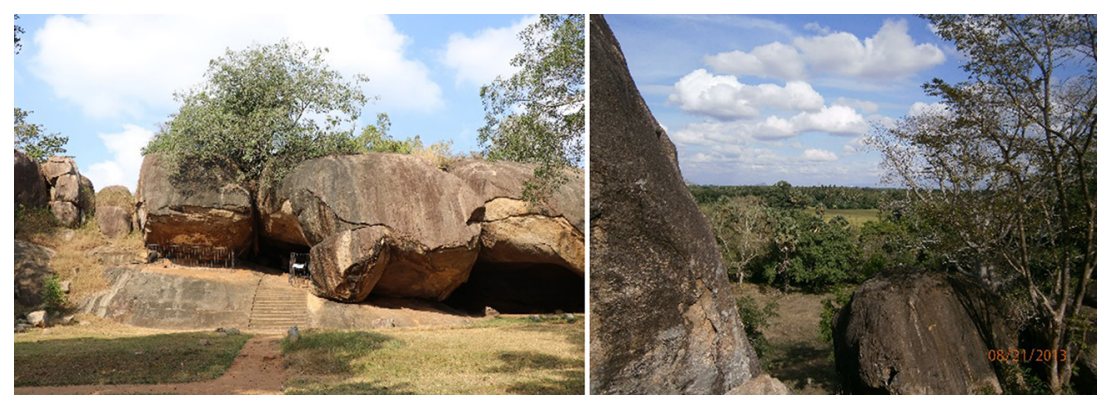

Figure 4: Granite formation - caves, rocks \& boulders, stone terrains. 


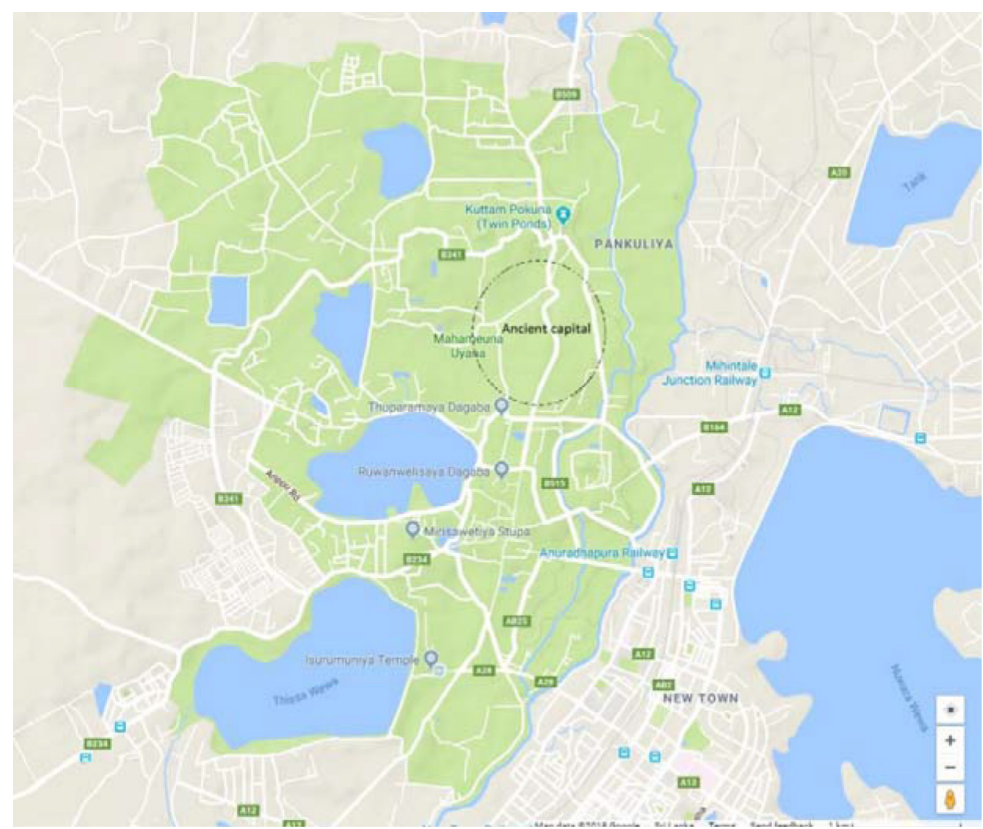

water

Figure 5: Agriculture landscape encircle the old city.

Vijaya was the first king of this civilization. The second Anuradha was a prince, one of six brothers of princess Bhaddakachana, the daughter of a Sakyan king, who arrived in Sri Lanka with thirty-two maidens for the consecration of Panduvasudeva (444 BCE-414 BCE). Her six brothers arrived later to Sri Lanka and settled down at different places, according to their wish. One of her brothers, Anuradha, built Anuradhagama. 'Anuradha built a tank, and when he had built a palace to the south of this, he took up his abode there.' This gives an important insight to the long history of urbanism, settlement and the agriculture and irrigation of Sri Lanka. For the building of a tank, he might have utilized indigenous knowledge and workforce (of pre-Vijaya); the storage of water should be for the irrigation and cultivation, as Malwathu Oya nearby was well enough for the daily consumption. This geographical and historical information is evidence of the anthropological ethnographical experience of the

\section{Land extent (Hectares)}

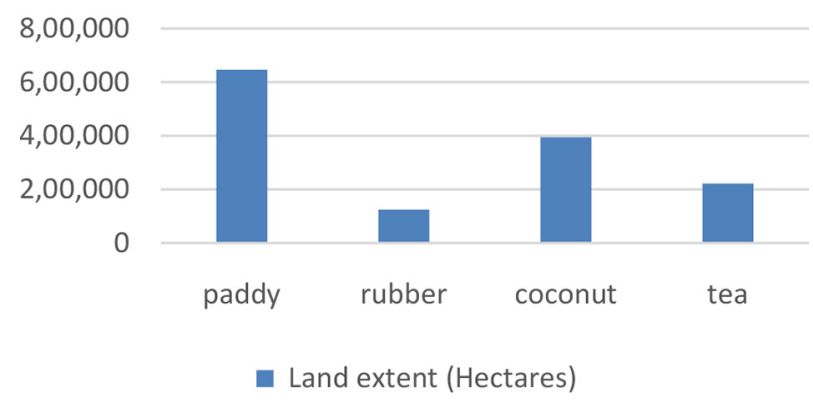

Figure 6: Land extent of crops. 
natural landscape location of Anuradhapura as important for a human settlement, which guides the dwelling, process of dwelling and the orientation of the place.

\section{ORIENTATION OF THE CITY}

The orientation of the city Anuradhapura is examined through different periods, to evaluate the understanding of natural landscape, topography and geographical location, for a sustainable city. This phenomenological basis provides an important beginning for the discussion.

\subsection{Dwelling and orientation of the place}

People experience their existence on the earth as dwelling, when experiencing the sense of place in the location, where they live [2]. The sense of place is the experience of place attachment; when people have this experience, they belong to the location/physical setting and their existence is part of the surrounding. The sense of place signifies an effort to understand the place through the process of dwelling, which is an essential aspect of human nature [3]. Considering Heidegger's phenomenology, Norberg-Schulz advances the idea, that people understand the nature and natural landscape, in the process of dwelling, through the way they live on the earth, focusing on the European context. However, the process he mentioned is less emphasized. Performance indicates the process, [10] through a tiring life on the earth, through which the way people work on the earth. The roughness of the earth surface provides a basic setting for the interactions between the body and the topography. The earth surface, the topography as the primary foothold, for the dwelling, guides the orientation of the place [3].

Norberg-Schulz explains that the orientation of a place/urban place is mainly due to the elements of the natural landscape, geographical formation and geometry, and due to this orientation, the 'spirit of the place,' the genius loci which is intrinsic to that location reflects upon the landscape. Architecture and urban landscape reflect the genius loci (in good architecture). Hence, the orientation of a place signifies spiritual experience. The spiritual experience of the natural landscape is discussed by many [7],[3],[11],[12], due to the geographical, geometrical formations, which arouse something universal, in the human mind. According to Norberg-Schuz, the understanding of the orientation of the natural landscape location is through a process of dwelling encountering the sense of place. The geographical, geometrical orientation directed by the natural formations, directs the spirit of place, which is identical to that location. However, the process of dwelling in terms of the understanding orientation is less recognized.

\subsection{Orientation of Anuradhapura}

The historical evaluation of Anuradhapura city throughout different periods illustrates how the orientation of the place is understood through the identification of the geographical/ geometrical formation of the natural landscape, and manifests in the built space. As discussed earlier, during the pre-historic time, this site attracted wandering people to settle due to the natural orientation, directed by the sacred natural elements. Abundant water supply from the river and the linear shape of the rock formation, comprised of rocks and caves for life expression, other than the simple need of shelter, have defined a stretch of land area in-between, for the cultivation and farming for the earliest wandering people, to settle in these areas to experience the process of dwelling (Fig. 7a). Therefore, these early settlers of the stoneage and later iron age might have experienced sacred dimensions among these rocks, boulders, caves, mountains, water and grooves through inhabitation in the landscape.

The orientation directed by the geographical location was interpreted in Buddhist history of Sri Lanka. Buddha visited the Anuradhapura during the third visit to Sri Lanka, seated with his 


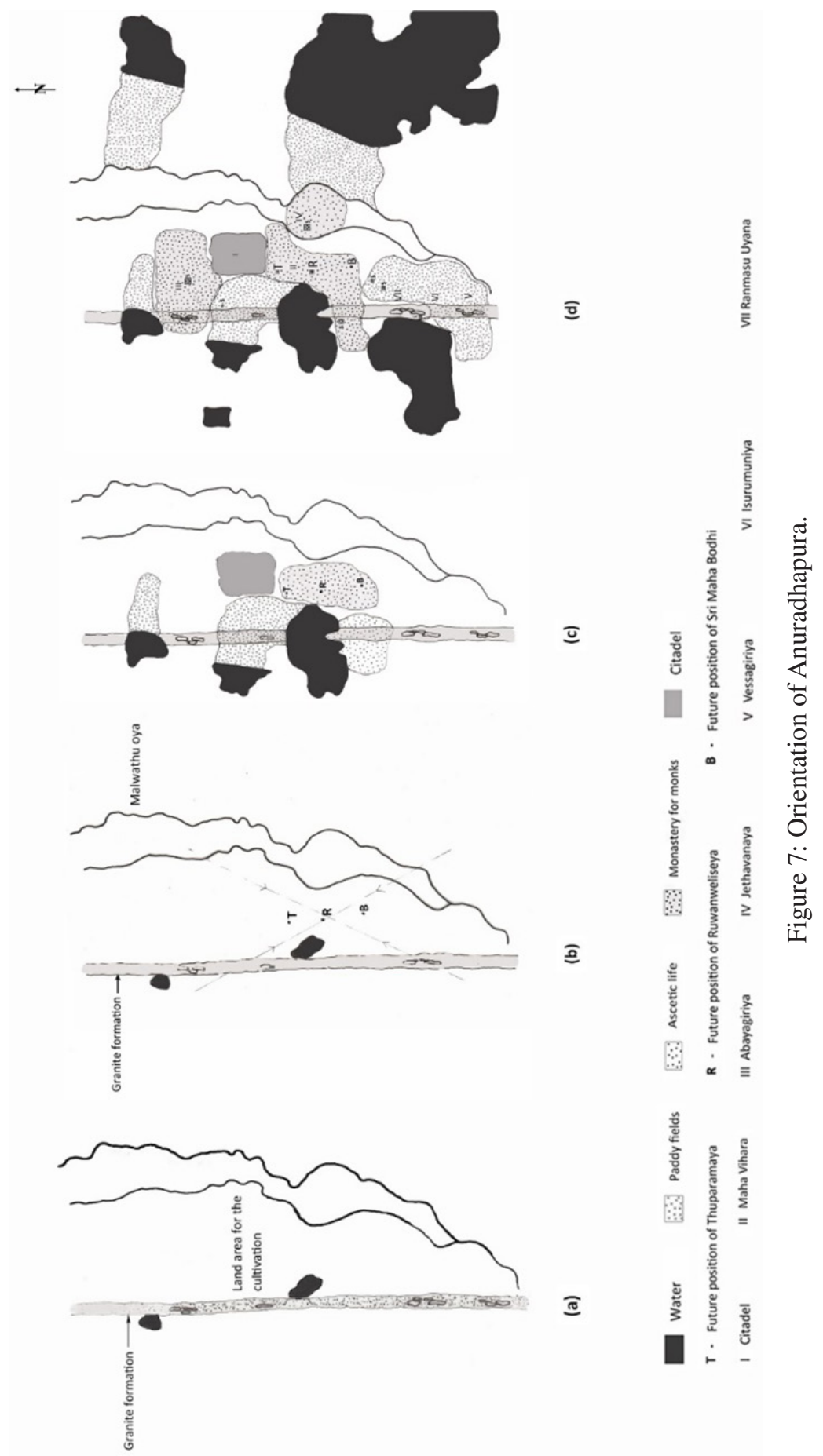


disciples, in a meditative posture, at the places where the great Tupa (present Ruwanwelisaya), Thuparamaya and sacred Bodhi tree coming afterward, marked three important points. The interpretation of these three points as fundamental points of the spatial orientation, and as three important built and natural elements in future city, further strengthen the orientation directed by the geographical/geometrical location, following the natural landscape (Fig. 7b). As discussed by Norberg-Schulz, understanding nature and natural landscape is through visualization, complementation, and symbolization [3].

The settlement of Anuradha has been converted to the Anuradhapura (pura:city) by Pandukabhaya (377 BCE-307 BCE). This city has two or more tanks for the cultivation. The location of the citadel and the area assigned for spiritual observation, follow the orientation directed by the natural landscape elements (Fig. 7c). The city being on the left bank of the river, in contrast to Aryan cities on the right bank, could justify this view. Pandukabhaya's city was a 'performing system' of the same agriculture irrigation settlement, in an urban scale.

The introduction of Buddhism, during the reign of Devanampiyatissa (247 BCE-207 $\mathrm{BCE}$ ), by Arhat Mahinda (from India) made a significant contribution to advancing the urban landscape to the Buddhist sacred city Anuradhapura. The growing demand for food due to the increasing number of urban population in monasteries, worshiping places, related services, and the workforce employed in new constructions, reshaped the landscape and urban agriculture achieving the new balance and created a Buddhist sacred city [1]. However, the new city comprehends the same orientation directed by the natural landscape elements. Adding three more large wewa, and related agriculture lands further strengthened the orientation (Fig. 7d). The citadel and monasteries were in the same location as in the Pandukabhaya's city, continuing the same anthropological - ethnographical understanding. Agriculture and irrigation signify the boundary/periphery of the urban landscape while the centre is represented by the stupa, monasteries and the citadel.

In brief, the orientation in Anuradhapura directs the centre, physically and non-physically. In the urban landscape, centre is symbolized through piers of the stupa, urban monasteries, and citadel, while agriculture and irrigation at the periphery enhance the centre. The centre is recognized as sacred, having spiritual experiences in many cultures, an essential dimension of the place [13],[14],[15],[16]. Therefore, the orientation of the Buddhist city Anuradhapura guides the sacred dimensions.

\section{ROLE OF THE BODY IN AGRICULTURE}

Examination of contextual concepts and the four noble truths in Buddhist philosophy would reveal more explanations on how people understand the orientation in everyday life while working in the fields, through the process of dwelling, and performing agriculture activities and engaging with the earth surface.

\subsection{Ploughing ceremony}

Mahavamsa mentioned that a 'ploughing ceremony,' as an establishment of boundaries, is an important phenomenon to understand the founding of these settlements and their relevance to the agriculture. It is said that 'Pandukabhaya, (377 BCE-307 BCE) the ruler of Lanka established the village boundaries over the whole of the island of Lanka'. In another similar event, the king Devanampiyatissa (247 BCE-207 BCE) asked from the Arhat Mahinda, 'Does the doctrine of the conqueror stand Sir?'. However, the thera replied that it is not yet until the boundaries are established. 'Therefore, he established the boundaries with all speed, taking in the city.' Further, 
this ritual process is explained as a ceremony king adorned with all his ornaments, with the participation of ministers and queens. 'The king ploughed a furrow in a circle, making it to begin near the ford on the Kadamba river, and ended it when he (again) reached the river.' It might be inclusive of the whole city limits, including the inner city and monasteries. Further, he had assigned boundary marks on the furrow that the king had ploughed and had assigned them to several other inner buildings/places. According to these descriptions, the king has ploughed the peripheries of the marked places; marked a sanctity, for the survival of a settlement upon the agriculture. Also, this symbolizes the anthropological, ethnographical understanding of the placing of settlements, through seedling and agriculture. Ploughing of a land as a means to sanctify and take possession for the purpose of construction or founding of a town [17]. These kinds of ploughing ceremonies are common in an Asian region, still, celebrated in various scales. Marking of a circle and circumbulation in these rituals establish important dimensions of the place: centre, enclosure, ordered world and inside and outside. Ploughing ceremony symbolizes the importance of agriculture, to actively engage people with the topography and the land, and to direct the orientation of the place, the sanctity. Hence, these rituals symbolize a 'performative process' for dwelling, through a tiring work, ploughing on the earth, to understand their existence. Another important aspect implied is the boundary/periphery in the form of agriculture for the existence of the centre - citadel and the urban monasteries in the physical world.

\subsection{Four noble truths}

The examination of the 'four noble truths,' the universal truth, as the basic concept of Buddhist philosophy, further explains how everyday life relates to the place and the sacred experience. The four noble truths are: pain, the origin of pain, stopping of pain and leads to its stopping could be understood by relating to the 'ploughing ritual.' Pain is the sensory feeling - sense and feeling of the mind-body experience by arduous work, by sensing the roughness of the earth, its impact, and resistance to the body, body reactions to the heat of the sun and the climate, and the understanding of topography. The origin of the pain is the reason, which is earthly, physically bounded, by engaging in ploughing: inter-action developed between the ploughing and the topography. Pain and origin of pain together lead to stopping, which creates the sanctity of no pain.

'The orientation' of Norberg-Schulz, could be further advanced in this view. The experience of the sacred dimensions in the orientation is through actions and painful life on the earth; no pain through pain, the interactions of the body with the topography. This experience relates to the same experience directed in the natural landscape, as the natural orientation, which is an embodied experience of the self and the landscape/surrounding [10].

\subsection{Embodied agriculture landscape}

As discussed above, anthropo-ethnographical experience is essential in placing settlements and selecting the appropriate sites. As discussed elsewhere, early pre-historic people, then people before the arrival of Vijaya and after Vijaya, Pandukabhaya, Devanampiyatissa and Arhat Mahinda would have experienced the embodied landscape and recognized the orientation given by the stretch of land in between Malwathu Oya and the granite formation as reflecting sacred dimensions for the establishment of a city or a settlement. Arhat Mahinda himself selected the sites for 'fitting and unfitting for buildings \& Buddhist landscape' [9]. Arhat Mahinda was a wise monk, who attained the highest level of the ordination of arhatship, who received a multi-dimensional vision of past, present, and future, the highest level of spiritual power. 
An embodied landscape is a newly developing phenomenon in landscape research, it describes the experience of the body and the surrounding landscape as one [18],[19]. The discussion of the body as embodied paradigm [20], lived body [21], describes the extended relationship between the body and the surrounding. Embodied cognition is another area integrating phenomenology, science and Buddhist practise [22]. Embodied mind introduced a new form of cognitive science called, 'enaction,' in which both the environment and first-person experience are aspects of embodiment. However, enactive embodiment is not the grasping of an independent outside world by a brain, a mind, or a self, rather it is the bringing forth of an independent world in and through embodied action. Therefore, the active body in agriculture, institutes an embodied space, through interactions between the body and the topography and the roughness of the earth surface, to understand the pain and the origin of the pain together to lead to the sanctity of no-pain. Through these actions and processes, people experience sanctity dynamically, which is a good experience for human well-being and the existence on the earth. 'Spiritual experiences are robust states that may have profound impacts on people's lives,' Marc Potenza [23].

\section{PERFORMING AGRICULTURE IN ANURADHAPURA}

This section discusses, how agriculture-related actions and activities are performed in the landscape, Anuradhapura. As discussed, the city Anuradhapura has been evolved from the small tank fed village to the circle of tanks \& agriculture lands at the periphery. Furthermore, the practical issue of collecting water across the topography \& landscape shape these settlements: understanding the natural landscape. The simplest version of building a tank establishes an integrated system of village/city, water, cultivation and sacred landscape, and people through activities. It is as an independent sustainable unit of balance between the production and the need, as well as the psychological balance in the embodied landscape.

The tank is done by blocking a water stream by a dam; the collected water becomes a storage tank, conveyed through a canal system to paddy fields on the other side of the dam. There is a small settlement by the side of the paddy fields; agriculture is an integral part of their life rather than an occupation. There are chena cultivation (rainfed) and reserved areas for trees, as water catchment areas, which highlight the ecological balance (Fig. 8). These kinds of smaller tanks are organized into a cascading sequence; drainage from the paddy fields in the upper part of the cascade flowing into a downstream tank for reuse in the paddy fields below formed a network of cascades across the north-central lowland of the country.

Although the main grain is paddy in the lowland areas, there are other varieties of grain cultivations. In paddy fields, from the seedling stage to the harvesting stage, there are many rituals and festivals to celebrate these by performing. There are distinct dialects for each event, for example, in irrigation works, ploughing ceremonies, paddy fields, harvesting field and in Kamatha activities. The ploughing ceremony is performed at a pre-determined auspicious time, recognized by the astrologers (who are specialized in traditional knowledge). The origins of these traditions might have links with the ploughing ceremony of Devanampiytissa/Pandukabhaya or further back in time. They do plough for three times, different names for each ploughing, after that they divert water from the irrigation channels. Seeding is another ritual event performed at an auspicious time and date. Throughout the seedling to ripen stage, farmers have to keep an eye on wild seeds and protect them from wild animals and birds. Margins of the paddy fields are reserved for birds. Harvesting is a community activity with participating neighbours and the 


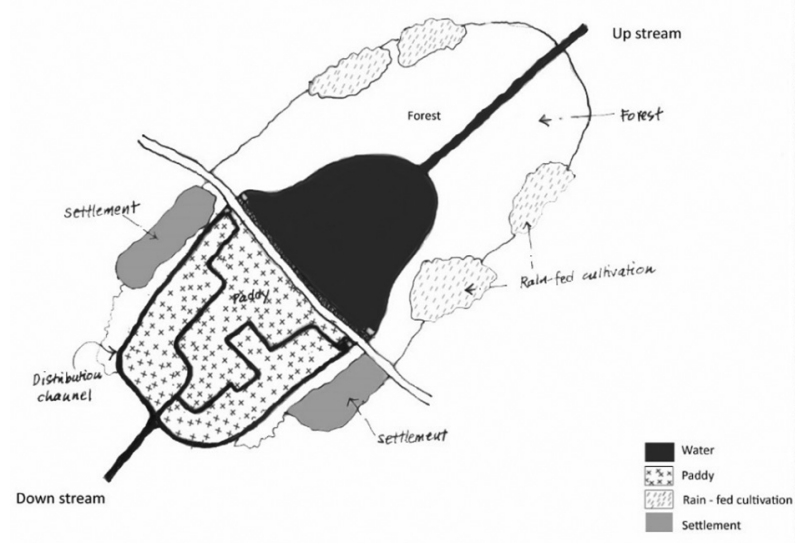

Figure 8: Tank fed agriculture settlement.

villagers, celebrated through various festivals. Singing folk poems throughout these performing activities is common and specific for each event, creating a celebrative atmosphere, despite the tiring work. Kamatha is a special spiritualized purified area, utilized for separate seeds from the leaves, celebrated with rituals and ceremonies (Fig. 9). In all these events and activities, people sense \& experience the nature, the direct relationship of the nature to the body; water and its freshness, muddy water, flowing quality, sounds, mud, earth, hardness of the earth surface, warm air, heat of the sun, humidity, shades of trees, winds, rain, birds and animal behaviour, sounds of lives, etc. Therefore, after working in the fields, bathing in water tanks, the experience of the refreshing sacred quality of water, in the vicinity of piers of the stupa across the paddy fields would refresh their bodies and minds, recognizing the sacred dimensions, uplifting the nature of humans and wellbeing.

All these indicate, how people celebrate the cultivation and related experiences by performing agriculture and engaging with topography and the landscape. By the tiring work of ploughing, sensing the pain and the origin of the pain bounded to the earth, the sense of place and the place attachment is experienced in the process of dwelling. All the associated rituals are evidence of the spiritual experience gained through these performing processes.

These ploughing ceremonies indicate the establishment of boundary of ploughing/agriculture as an essential process for the existence of the centre physically and non-physically. The sanctity represented by monasteries and stupa, physically in the city centre. Therefore, ploughing and cultivation is a mechanism to engage the people, in the boundary of the place for the existence of the centre of the place and the city, and to experience the orientation of the place (Figs. 10 \& 11). Table 1 summarises the links of urban agriculture with universal and Buddhist concepts. 


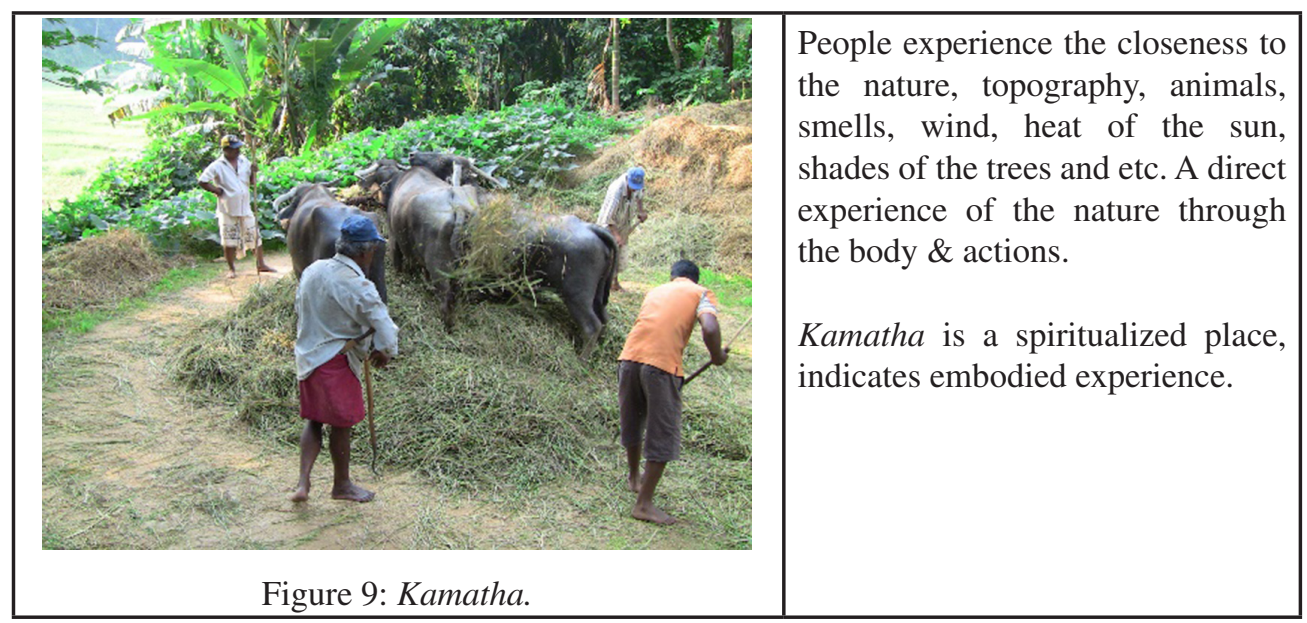

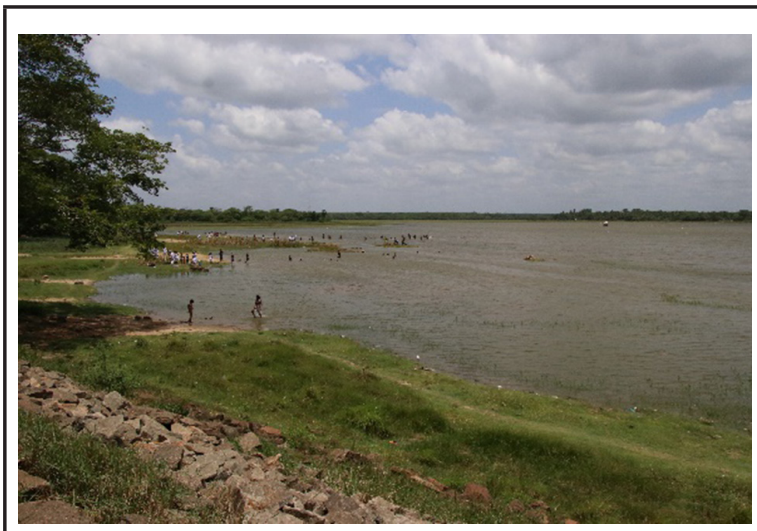

Figure 10: Water tanks (wewa) at the boundary.
People sense \& experience the direct relationship of the nature to the body; water, its freshness, flowing quality, sounds of water \& air, quality of water in relation to the hardness of the earth surface \& the heat, etc.

Experience the refreshing quality of water, in the vicinity of piers of the stupa, refresh their bodies and minds, uplifting the nature of humans and wellbeing.

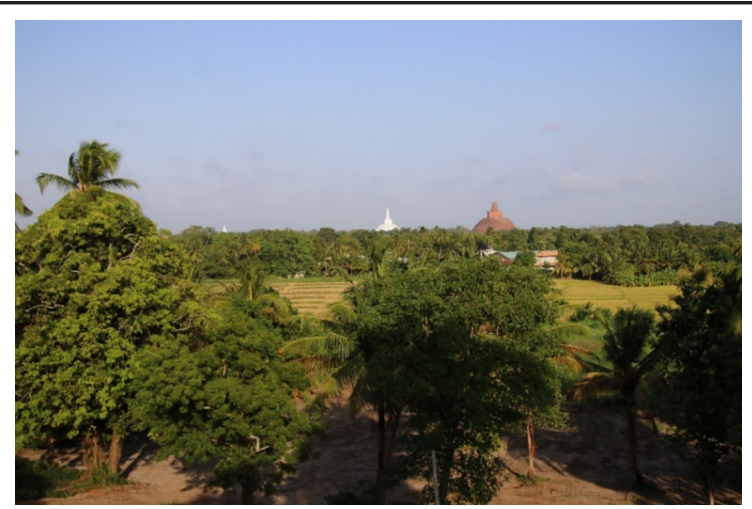

Boundary: agriculture \& irrigation landscape, Centre: stupa \& monasteries and the citadel.

Boundary of ploughing for the existence of centre of the place.

Figure 11: Vicinity of stupa at the centre, across the paddy fields. 
Table 1: Urban agriculture links to universal and Buddhist concepts.

\begin{tabular}{|c|c|c|c|}
\hline $\begin{array}{l}\text { Universal } \\
\text { Concepts }\end{array}$ & $\begin{array}{l}\text { Buddhist concepts \& } \\
\text { Anuradhapura }\end{array}$ & Urban agriculture & $\begin{array}{l}\text { Current } \\
\text { discussions }\end{array}$ \\
\hline $\begin{array}{l}\text { People experience } \\
\text { their existence on } \\
\text { the earth and the } \\
\text { place }\end{array}$ & & $\begin{array}{l}\text { Agriculture as a } \\
\text { process of dwelling } \\
\text { to understand the } \\
\text { existence. }\end{array}$ & $\begin{array}{l}\text { Dwelling, sense } \\
\text { of place, place } \\
\text { attachment, per- } \\
\text { forming place. }\end{array}$ \\
\hline $\begin{array}{l}\text { Orientation of } \\
\text { the place directs } \\
\text { sacred dimen- } \\
\text { sions. Nature \& } \\
\text { natural landscape } \\
\text { elements direct } \\
\text { orientation. }\end{array}$ & $\begin{array}{l}\text { Buddha marked three } \\
\text { points, which emphasize } \\
\text { the orientation between } \\
\text { river and the granite } \\
\text { formation. (Fig. } 7 \mathrm{~b} \text { ) }\end{array}$ & $\begin{array}{l}\text { Selection of the site } \\
\text { for agriculture-based } \\
\text { settlement. }\end{array}$ & $\begin{array}{l}\text { Spirit of the } \\
\text { place/genius } \\
\text { loci, architec- } \\
\text { ture \& urban } \\
\text { landscape reflect } \\
\text { the spirit of the } \\
\text { place. }\end{array}$ \\
\hline $\begin{array}{l}\text { Understanding the } \\
\text { orientation of the } \\
\text { place/ landscape }\end{array}$ & $\begin{array}{l}\text { Great stupa marked } \\
\text { the center/ orientation. } \\
\text { City developments } \\
\text { emphasize the original } \\
\text { orientation, and spirit of } \\
\text { the place. }\end{array}$ & $\begin{array}{l}\text { Agriculture \& irriga- } \\
\text { tion at the periphery } \\
\text { emphasize the centre/ } \\
\text { orientation of the city. }\end{array}$ & $\begin{array}{l}\text { Dwelling as } \\
\text { a process to } \\
\text { understand the } \\
\text { orientation. } \\
\text { Visualization, } \\
\text { complementa- } \\
\text { tion \& symbol- } \\
\text { ization. }\end{array}$ \\
\hline \multirow{2}{*}{$\begin{array}{l}\text { Four noble truths } \\
\text { - Pain, origin of } \\
\text { the pain, stopping } \\
\text { of pain, leads to } \\
\text { stopping } \\
\text { Four noble truths } \\
\text { explain how } \\
\text { people experience } \\
\text { their life existence } \\
\text { on the earth. }\end{array}$} & $\begin{array}{l}\text { Ploughing ceremony } \\
\text { marks a sanctity, which } \\
\text { leads to no pain, with } \\
\text { the help of pain (agri- } \\
\text { culture) at the periphery. }\end{array}$ & \multirow[t]{2}{*}{$\begin{array}{l}\text { Through laborious } \\
\text { work of agriculture } \\
\text { people experience the } \\
\text { spirituality; orientation } \\
\text { of the place, physically } \\
\text { and non-physically. }\end{array}$} & $\begin{array}{l}\text { Centre and } \\
\text { periphery are } \\
\text { important di- } \\
\text { mensions in the } \\
\text { place. }\end{array}$ \\
\hline & $\begin{array}{l}\text { Agriculture in the } \\
\text { periphery and sacred } \\
\text { stupa/ monastery/city in } \\
\text { the centre co-exist, to } \\
\text { perform Buddhist city. }\end{array}$ & & $\begin{array}{l}\text { Embodied land- } \\
\text { scape/ agricul- } \\
\text { ture }\end{array}$ \\
\hline $\begin{array}{l}\text { Human wellbeing: } \\
\text { physically and } \\
\text { non-physically }\end{array}$ & $\begin{array}{l}\text { Physically \& spiritually, } \\
\text { socially, culturally, eco- } \\
\text { nomically, balanced }\end{array}$ & $\begin{array}{l}\text { Laborious work uplifts } \\
\text { the body for healthy } \\
\text { body \& mind through }\end{array}$ & $\begin{array}{l}\text { Wellbeing, } \\
\text { sustainability, } \\
\text { healthy city. }\end{array}$ \\
\hline & $\begin{array}{l}\text { city: an independent } \\
\text { sustainable unit. }\end{array}$ & $\begin{array}{l}\text { embodied actions and } \\
\text { landscape; establish a } \\
\text { healthy space for well- } \\
\text { being of both body \& } \\
\text { mind. }\end{array}$ & \\
\hline
\end{tabular}




\section{CONCLUDING DISCUSSION: HEALTHY SPACE FOR WELLBEING}

\subsection{Healthy space}

From the ploughing stage to the harvesting stage, the body condition is activated through a series of body movements, through performing various actions, (rituals/cultural/functional) across the topography, as well as sensing the authentic experience of the outside space: air, water, wind, sun, heat, rain, etc. Tiring working in the fields, increases the physical health, balancing body conditions: blood sugar level, blood pressure, heartbeat, muscular strength, and maintaining a healthy body, balancing the metabolic conditions. This work would have established a balance condition between the body and outside space - landscape, extending the body, for the embodied status. These would be further research areas. Through all these processes of performing actions and everyday life of people, a spatial network is produced incorporating paddy fields, water tanks, trees \& grooves, rocks and boulders, topography, Malwathu Oya, stupa, monasteries, and citadel: producing a healthy space for the life existence and for its continuation.

Performing rituals and festivals related to cultivation, images of the stupa and paying homage to the sacred landscape, and recognizing the orientation of the place, are evidences of spiritual experience of the space. Eventually, all these imply a profound impact on people's lives, which transcends good to space, creates a positive and healthy space in the city. Therefore, healthy mind-body and healthy space together would guide the orientation, for a sustainable landscape and a city.

\subsection{Sustainable city and human wellbeing}

These concepts shape the city form, integrating urban and agriculture landscape, in order to perform life in the Buddhist city Anuradhapura. In the Buddhist sacred place of Anuradhapura, the centre is represented by the number of great stupa, resembling the mountains, a vital element in the sacred landscape, while water tanks, another sacred element, encircle the city, attached to paddy fields and everyday life performance of people which represents the periphery, the boundary of the place. Monasteries spread over large areas are noticeable at the centre of the city. Therefore, a large number of clergy, who attained to the higher ordination or near to the higher ordination depend on the laborious works of the everyday life of the people, who are attached to the irrigation and cultivation lands at the periphery. Through hard working, well-being and serving the centre, they also enter to the sanctity, to higher levels of minds. All these create the Buddhist sacred city and atmosphere in Anuradhapura.

Therefore, the examination of the Anuradhapura Buddhist city discloses deep roots, leads to understanding the sustainability through further research. The agriculture concept in the Buddhist city Anuradhapura is a mechanism to activate the role of the body and creates a healthy space, and vice versa, to uplift the nature of humans for wellbeing. These reflect on the city and the landscape, arouse the mind to understand the universal truth.

In conclusion, urban agriculture establishes a dynamic spatial relationship between the body and the topography within the boundaries of the city, physically, and non- physically, which evokes the embodied agriculture-based landscape, which brings healthy space for wellbeing both physically and non-physically.

\section{ACKNOWLEDGEMENTS}

Senate Research Council grants, University of Moratuwa, Sri Lanka 


\section{REFERENCES}

[1] De Silva, Urban agriculture and sacred landscape: Anuradhapura sacred city, Sri Lanka. WIT Transactions on Ecology and the Environment, 217, pp. 941-952, 2018.

[2] Heidegger, M., Being and Time, Harper \& Row: New York, 1962.

[3] Norberg-Schulz, C., Genius Loci: Towards a Phenomenology of Architecture, Rizzoli: New York, 1980.

[4] Dereniyagala, S.U., The Prehistory of Sri Lanka: An Ecological Perspective, Archaeological department: Sri Lanka, 1992.

[5] Wickramanayake, T.B., The beginnings of rice cultivation in Sri Lanka. Journal of the Royal Asiatic Society of Sri Lanka, 53, pp. 203-218, 2007.

[6] Herath, M.B., Archaeological remains of Thissa wewa Anuradhapura. Ancient Ceylon: Journal of the Department of Archaeology, Sri Lanka, 24, pp. 57-103, 2015.

[7] Eliade, M., Patterns in Comparative Religion, translated to English by Sheed, R., Cleveland: New York, 1965.

[8] Chandraratne, R.M.M., Faunal remains from the gedige excavation in 1985. Ancient Ceylon: Journal of the department of archaeology, Sri Lanka, 24, pp. 1-13, 2015.

[9] Geiger, W., The Mahavamsa :The Great Chronicle of Ceylon, (translated to English by Geiger in 1912), 3rd print, Buddhist cultural centre: Colombo, 2007.

[10] De Silva, W., Performing Place: Natural Landscape, Cultural Place, Performances of Sri Lankan Traditional Settlements, Kandy and Lankathilaka, Ph.D. Thesis, University of Nottingham UK, 2014 (published in e-prints, University of Nottingham; published in EThOS e-thesis, British Library, 2014).

[11] Sinha, A., Landscapes in India: Forms and Meanings, University press: Colorado, 2006.

[12] De Silva, W., Nature and Buddhist architecture: Sri Lanka. International Journal of Design \& Nature and Ecodynamics, 12(2), pp. 225-234, 2017. https://doi.org/10.2495/ dne-v12-n2-225-234

[13] Bollnow, O.F., Human Space, translated to English by Shuttleworth, C. \& ed. J. Kohlmaier, Hyphen: London, 2011.

[14] Norberg-Schulz, C., Existence, Space and Architecture, Praeger: London, 1971.

[15] Eliade, M., The Sacred and the Profane: The Nature of Religion, Harcourt: New York, 1968.

[16] De Silva, W., Otto Friedrich Bollnow's concept of human space, A critical discussion on the fundamentals of the concept of space. Built-Environment Sri Lanka, 7(2), pp. 40-42, 2010. https://doi.org/10.4038/besl.v7i2.1942

[17] Rykwert, J., Idea of a Town: The anthropology of urban form in Rome, Italy and the ancient world, Faber \& Faber: London, 1976.

[18] Bender, B., Time and landscape. Current Anthropology, 43, pp. 103-112, AugustOctober 2002.

[19] Doughty, K., Walking together: The embodied and mobile production of a therapeutic landscape. Health \& Place, 24, pp. 140-146, 2013. https://doi.org/10.1016/j.healthplace.2013.08.009

[20] Hale, J., Critical phenomenology: Architecture and embodiment. Architecture and Ideas, 12, pp. 18-37, 2013.

[21] William, S. J. \& Bendelow, G., The Lived body, sociological themes, embodied issues, Routledge: London, 1998.

[22] Varela, F.J., Thompson, E. \& Rosch, E., The Embodied Mind: Cognitive Science and Human Experience, MIT Press: Massachusetts, 2017.

[23] Where the Brain Processes Spiritual Experience. Yale News, Online, https://news.yale. edu/2018/05/29/where-brain-processes-spiritual-experiences, 29 May 2018. 